\title{
Penghitungan Jumlah Bakteri Yogurt Berbasis Threshold
}

\author{
Andi Sri Irtawaty \\ Jurusan Teknik Elektronika \\ Politeknik Negeri Balikpapan \\ Jl. Soekarno Hatta Km. 8, Balikpapan \\ irtawaty@yahoo.co.id
}

\begin{abstract}
Technological developments in the yogurt industry, has demanded us to create an innovative and creative are required. Taste and flavor derived from fermented starter. Where is the starter used in the fermentation process is a type of bacteria Lactobacillus bulgaricus and Streptococcus thermophilus. The composition is ideal for both bacteria was $1: 1$

The purpose of this study is to calculate the quantity of bacteria in the packing of sample $200 \mathrm{ml}$ yogurt and facilitate the experts to make calculation of compotition LB and ST automatically. In this case, the method used is a method based on the determination of threshold. Accuracy of performance of this method achieve of $90.37 \%$.
\end{abstract}

Keywords : bacteria, threshold

\begin{abstract}
Abstrak
Perkembangan teknologi di bidang industri yogurt, telah menuntut kita untuk menciptakan suatu inovatif dan kreatif yang diperlukan. Cita rasa dan aroma yang khas diperoleh dari hasil fermentasi starternya. Dimana starter yang digunakan dalam proses fermentasi ini berupa bakteri jenis Lactobacillus Bulgaricus (LB) dan Streptococcus Thermophilus (ST). Komposisi yang ideal untuk kedua bakteri tersebut adalah 1:1

Tujuan dari penelitian ini adalah menghitung jumlah bakteri pada sampel kemasan yogurt $200 \mathrm{ml}$, baik dalam suhu kulkas maupun dalam suhu kamar serta memudahkan para ahli di bidang industri yogurt untuk melakukan penghitungan komposisi bakteri LB dan ST secara otomatis. Dalam hal ini, metode yang digunakan yaitu suatu metode yang berdasarkan penentuan nilai ambang. Keakuratan kinerja metode ini mencapai $90,37 \%$.
\end{abstract}

Kata kunci : bakteri, nilai ambang

1. Pendahuluan

1.1 Latar belakang

Yogurt merupakan produk susu yang dihasilkan melalui proses fermentasi. Asalnya dari Bulgaria dan China. Namun dalam pencatatan awal, yogurt berasal dari dinasti Jin. Fermentasi dari laktosa menghasilkan asam laktat yang bekerja pada protein susu sehingga membuat yoghurt lebih padat serta memiliki tekstur dan aroma yang khas.

Yogurt dikenal masyarakat karena memiliki kadar nutrisi yang tinggi, cita rasa yang enak dan memiliki banyak manfaat, diantaranya menurunkan berat badan, menurunkan kadar kolesterol darah, menjaga kesehatan lambung, dan mencegah penyakit kanker saluran pencernaan.

Starter bakteri yang digunakan adalah bakteri Lactobacillus Bulgaricus dan Streptococcus Thermophilus. Lactobacillus Bulgaricus termasuk jenis bakteri homofermentatif, berbentuk basil (batang) dan berwarna keunguan. Bakteri ini berukuran 0,5-0,8 x 2-9 $\mu \mathrm{m}$. Bakteri ini dapat memecah gula menjadi asam laktat dan dapat tumbuh dengan baik pada suhu $37^{\circ} \mathrm{C}$. Sedangkan Streptococcus Thermophilus merupakan jenis bakteri berbentuk coccus (bulat), berwarna kebiruan dan dapat tumbuh dengan baik 
pada suhu $45^{\circ} \mathrm{C}$. Bakteri ini memiliki diameter berukuran $<1 \mu \mathrm{m}$ dan juga dapat memproduksi asam laktat secara cepat pada kondisi anaerobik. Komposisi perbandingan yang ideal untuk kedua bakteri tersebut agar diperoleh cita rasa yogurt yang khas adalah 1:1.

\subsection{Pengolahan Citra Digital}

Pengolahan citra merupakan pemrosesan citra khususnya menggunakan computer agar mudah diinterpretasi oleh manusia atau mesin. Pengolahan citra bertujuan untuk perbaikan atau modifikasi citra, penggabungan citra dengan citra lainnya, dan juga digunakan jika suatu citra perlu dikelompokkan, dicocokkan atau diukur, dihitung kuantitasnya dan masih banyak lagi manfaat lainnya. Sedangkan pengertian citra adalah kumpulan pikselpiksel yang berisi informasi yang tersusun dalam bidang dua dimensi.

Pada umumnya citra digital merepresentasi piksel-piksel dalam ruang dua dimensi dinyatakan dalam matriks yang berukuran $\mathrm{M}$ baris dan $\mathrm{N}$ kolom, seperti ilustrasi persamaan 1 berikut ini :

$$
\begin{aligned}
& F=|f(i, j)|= \\
& {\left[\begin{array}{cccl}
f(0,0) & f(0,1) & \ldots & f(0, N-1) \\
f(1,0) & f(1,1) & \ldots & f(1, N-1) \\
\ldots & \ldots & \ldots & \ldots \\
f(M-1,0) & f(M-1,1) & \ldots & f(M-1, N-1)
\end{array}\right]}
\end{aligned}
$$

Nilai masing-masing elemen $f(i, j)$ dalam matriks $\mathrm{F}$ merepresentasikan intensitas warna dari citra yang terdigitasi. Setiap nilai dinyatakan dalam bentuk kode- kode biner, misalkan dalam 24 bit per piksel ( $24 \mathrm{bpp}$ ) untuk citra berwarna atau dalam 8 bit per piksel (8 bpp) untuk citra gray level. Berdasarkan bagaimana sebuah citra dikodekan inilah citra dapat dikelompokkan menjadi empat jenis yaitu : (1) citra index (index images) yaitu nilai piksel dari citra yang mengacu pada matriks peta warna, (2) citra grayscale (intensity images) yaitu setiap nilai piksel yang menunjukan intensitas tingkat keabuan dan setiap piksel didefinisikan sebesar 8 bit $\left(2^{8}=\right.$ 256), (3) citra biner (binary images), direpresentasikan dengan 1 bit per piksel di mana setiap piksel hanya memiliki 2 kemungkinan nilai yakni 0 atau 1 (on, off), (4) citra RGB (RGB Images) merupakan paduan tiga intensitas warna merah, hijau dan biru dan direpresentasikan dalam matriks 3 dimensi.

\subsection{Thresholding}

Thresholding merupakan proses pemisahan piksel-piksel berdasarkan derajat keabuan yang dimilikinya. Piksel yang memiliki derajat keabuan lebih kecil dari nilai batas yang ditentukan akan diberikan nilai 0 , sementara piksel yang memiliki derajat keabuan yang lebih besar dari batas akan diubah menjadi bernilai 1 .

\section{Metoda Penelitian}

Metoda yang digunakan dalam penelitian ini adalah metoda pengolahan citra berbasis thresholding.

Pengolahan citra yang dilakukan melalui 3 tahapan utama, yaitu (1) tahap akuisisi data, (2) tahap preprocessing dan segmentasi dan (3) tahap penghitungan kuantitas bakteri LB dan ST.

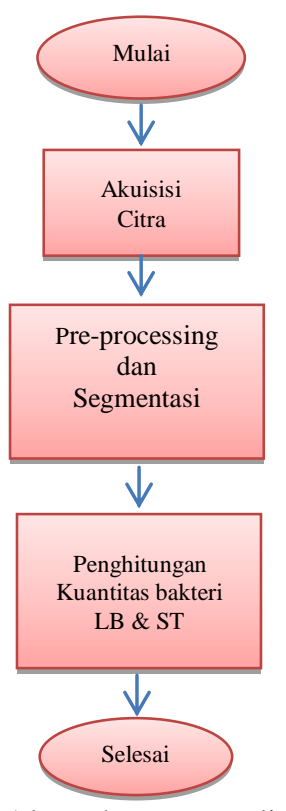

Gambar 1 Alur tahapan penelitian 


\section{Hasil Penelitian}

Analisa data penelitian berupa tampilan citra hasil capture yang dilakukan pada dua kondisi suhu, yaitu suhu kulkas $\left(<4^{0} \mathrm{C}\right)$ dan suhu kamar $\left(\geq 4^{0} \mathrm{C}\right)$, akan diuraikan secara rinci sebagai berikut :

\subsection{Penghitungan bakteri pada suhu kulkas}

Berdasarkan hasil simulasi selama 6 detik berurutan, diperoleh hasil penghitungan jumlah bakteri pada suhu kulkas seperti yang ditunjukkan pada tabel 1 .

Tabel 1 Jumlah bakteri per capture pada suhu dengan kulkas $\left(<4^{0} \mathrm{C}\right)$

\begin{tabular}{|c|c|}
\hline $\begin{array}{c}\text { Waktu } \\
\text { (detik) }\end{array}$ & $\begin{array}{c}\text { Jumlah bakteri } \\
\text { per capture } \\
\left(1024^{*} 1280\right) \text { piksel }\end{array}$ \\
\hline 0 & 31 \\
\hline 1 & 39 \\
\hline 2 & 31 \\
\hline 3 & 46 \\
\hline Rata-rata & 37 \\
\hline
\end{tabular}

Jumlah rata-rata bakteri untuk 4 kali capture

$=\frac{31+39+31+46}{4}=37$ bakteri.

Jika 1 Petroffhausser (preparat yang digunakan saat akuisisi data) terdiri atas

25 kotak, @1kotak=(600*600) piksel

$$
=360000 \text { piksel }
$$

25 kotak $=25 * 360000=9000000$ piksel

1 capture image $=(1024 * 1280)$ piksel

$$
\begin{aligned}
= & 1310720 \text { piksel } \\
& \quad \text { (terdiri atas } 37 \text { bakteri) }
\end{aligned}
$$

25 kotak $=0,01 \mathrm{ml}=\frac{9000000}{1310720} * 37$ bakteri

$$
=254 \text { bakteri }
$$

Maka 1 kemasan yogurt $200 \mathrm{ml}$ suhu kulkas $=200 * 254 * 100=5.080 .000$ bakteri
3.2 Penghitungan bakteri pada suhu kamar Berdasarkan hasil simulasi selama 4 detik berurutan, diperoleh hasil penghitungan jumlah bakteri pada suhu kamar seperti yang ditunjukkan pada tabel 2 .

Tabel 2 Jumlah bakteri per capture pada suhu dengan kamar $\left(\geq 4^{0} \mathrm{C}\right)$

\begin{tabular}{|c|c|}
\hline $\begin{array}{l}\text { Waktu } \\
\text { (detik) }\end{array}$ & $\begin{array}{c}\text { Jumlah bakteri } \\
\text { per capture } \\
(1024 * 1280) \text { piksel }\end{array}$ \\
\hline 0 & 14 \\
\hline 1 & 9 \\
\hline 2 & 7 \\
\hline 3 & 12 \\
\hline Rata-rata & 11 \\
\hline
\end{tabular}

Jumlah rata-rata bakteri untuk 4 kali capture

$=\frac{14+9+7+12}{4} \approx 11$ bakteri

Perhitungan selanjutnya sama persis dengan perhitungan bakteri pada suhu kulkas, sehingga diperoleh hasil sebagai berikut :

Jumlah bakteri untuk $0,01 \mathrm{ml}=\frac{9000000}{1310720} *$ 11

$$
\begin{aligned}
& =75.53 \\
& =76 \text { bakteri }
\end{aligned}
$$

Maka dalam 1 kemasan yogurt $200 \mathrm{ml}$ suhu kamar $=200 * 76 * 100=1520000$ bakteri

\section{Kesimpulan}

1. Kuantitas bakteri Lactobacillus Bulgaricus dan Streptococcus Thermophilus pada suhu kulkas $\left(<4^{0} \mathrm{C}\right)$ untuk sample kemasan yogurt $200 \mathrm{ml}$ sebesar 5.220.000 bakteri.

2. Kuantitas bakteri Lactobacillus Bulgaricus dan Streptococcus Thermophilus pada suhu kamar $\left(\geq 4^{0} \mathrm{C}\right)$ untuk sample kemasan yogurt $200 \mathrm{ml}$ sebesar 1.520 .000 bakteri. 


\section{Saran}

Penelitian ini dapat dilanjutkan dengan menggunakan metode lain yang lebih sederhana (tanpa menggunakan operator).

\section{Daftar Pustaka}

[1] Roswita Sunarlim-H Adi SetiyantoDan Masniari Poeloengan, "Pengaruh Kombinasi Starter

Bakteri

Lactobacillus Bulgaricus,

Streptococcus Thermophilus Dan Lactobacillus Plantarum Terhadap Sifat Mutu Susu Fermentasi”, Seminar Nasional Teknologi Peternakan dan Veteriner, 2007.

[2] Dewi Yunita, Syarifah Rohaya, Nida El Husna, dan Isnanda Maulina, "Pembuatan Niyoghurt Dengan Perbedaan Perbandingan
Streptoccoccus Thermophilus dan

Lactobacillus Bulgaricus serta Perubahan Mutunya Selama Penyimpanan", Jurnal Teknologi Pertanian Vol.12 No.2 (Agustus 2011) 83-90.

[3] Achmad Noercholis, M. Aziz Muslim

dan Maftuch, "Ekstraksi Fitur Roundness untuk Menghitung Jumlah Leukosit dalam Citra Sel Darah Ikan", Jurnal EEECCIS Vol.7, No.1, Juni 2013

[4] R.C. Gonzales and R.E. Wood, "Digital Image Processing, Second Edition", Prentice Hall, 2002.

[5] Abdul Kadir, Adhi Susanto, "Teori dan Aplikasi Pengolahan Citra",2013. 